\title{
On human nature and human rights
}

\section{Citation}

Marks, Stephen P. 2013. On human nature and human rights. In Mensch und Recht - Festschrift zum 70. Geburtstag von Eibe Riedel, edited by Dirk Hanschel. Berlin: Duncker \& Humblot.

\section{Permanent link}

http://nrs.harvard.edu/urn-3:HUL.InstRepos:32310783

\section{Terms of Use}

This article was downloaded from Harvard University's DASH repository, and is made available under the terms and conditions applicable to Open Access Policy Articles, as set forth at http:// nrs.harvard.edu/urn-3:HUL.InstRepos:dash.current.terms-of-use\#OAP

\section{Share Your Story}

The Harvard community has made this article openly available.

Please share how this access benefits you. Submit a story.

Accessibility 


\title{
ON HUMAN NATURE AND HUMAN RIGHTS
}

\author{
Stephen P. Marks ${ }^{1}$
}

Are people innately good, but corruptible by the forces of evil? Or, are they instead innately wicked, and redeemable only by the forces of good? People are both. Edward O. Wilson ${ }^{2}$

\section{Outline}

A. Introduction: Ways of Understanding Human Nature and its Relations to Human Rights.

B. The Enlightenment Assumption that Human Rights Derive from Human

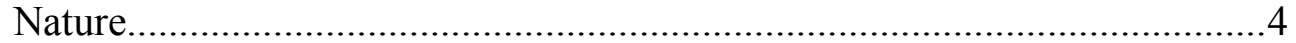

1. Merging of Science and Human Rights in the Enlightenment..............4

2. Development of Empirical Science in the 19th and 20th Century and Implications for Human Rights.............................................................5

C. Human Rights Implications of Scientific Knowledge about Human

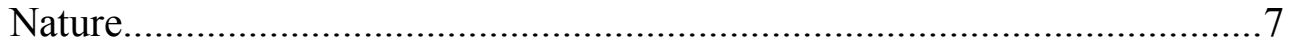

1. The Problem of Equality and Non-discrimination...............................9

2. Cooperation and Competition among Human Groups.........................12

3. The Problem of Violence....................................................................14

D. Conclusion: A New Enlightenment for Understanding the Relations between Human Nature and Human Rights .............................................16

\section{A. Introduction: Ways of Understanding Human Nature and its RELATIONS TO Human Rights.}

This essay takes as its starting point the concept of Der Mensch, which refers to the biological classification of the human sub-species (homo sapiens sapiens) among higher primates and specifically the family of the anthropoids, in addition to its more general meaning of a "person." That biological understanding is broadened by the concept of Menschlichkeit or humanity, from the Latin humanitas, which covers three meanings: the biological existence of the species, the broader sense of the various moral concepts of Enlightenment humanism, and the idea of humans' inherent ability to have compassion for other humans. Our inquiry builds on the juxtaposition of Mensch und Recht, implying that human beings function under the law and have rights as humans, hence the wordplay with Menschenrechte or human rights. This juxtaposition invites a reflection on

1 This essay is a chapter to be published in Dirk Hanschel (ed.), Mensch und Recht: Liber amicorum Eibe Riedel, 2013. The excellent research assistance of Sarah Raifman, Rachel Sandlow-Ash and Vera Sistenich is gratefully acknowledged.

2 Edward O. Wilson, The Social Conquest of Earth, New York, London: W. W. Norton \& Co., 2012, p. 241. 
how a progressively expanding set of subjective rights deemed inherent in all humans (human rights) relate to what we know about our nature as a species (human nature). Or, how does our scientific understanding of human nature relate to the legal and moral framework of human rights as it has evolved, particularly over the last seventy years?

This inquiry is not the result of an exhaustive study of such wideranging, challenging and cross-disciplinary issues. It has no greater claim than to suggest the potential value of a more sustained reflection. Such an invitation to further research bridging the legal and natural sciences seems a fitting tribute to Professor Eibe Riedel, who has ventured into these territories on more than one occasion. ${ }^{3}$ His inquiring mind and astute legal analysis should inspire others to take up the challenge to rethink human rights in light of advances in scientific approaches to understanding human nature.

It is rare to see this question posed in the human rights literature, which tends to explain human rights as deriving from natural law or positive law or both. Writings on the foundations of human rights tend not to inquire into whether and how scientific studies on the essence of human-ness (through biology and psychology) explain, if at all, the emergence of moral codes such as human rights. Human rights studies tend to draw upon findings of law, political science, public policy and philosophy. Jack Donnelly notes, "few issues in moral or political philosophy are more contentious or intractable than theories of human nature." $\mathrm{He}$ distinguishes "the scientist's

3 See, for example, Eibe Riedel, "The Constitution and Scientific and Technical Progress," in: Christian Starck (ed.): New Challenges to the

German Basic Law, Studien und Materialien zur

Verfassungsgerichtsbarkeit, vol. 49. Nomos, Baden-Baden 1991, p. 61 - 85; "On the Beginning of Life from a Constitutional Law Perspective. From the Procreation to the Creation of a Human Being" (original title: Zum Lebensbeginn in verfassungsrechtlicher Sicht. Von der Zeugung zur Erzeugung des Menschen), in: Gentechnologie und Fortpflanzungsmedizin - Chancen und Risiken, rechtliche und rechtspolitische Fragen, München 1989 (10 pp.); "Gene Technology in the Area of Conflict between Law and Ethics" (original title: Gentechnik im Spannungsfeld von Recht und Ethik), in: Alma Mater Philippina, Marburg 1991, p. 12 - 17; "Gene Technology and Embryo Protection as Constitutional Law and Regulatory Problems" (original title: Gentechnologie und Embryonenschutz als Verfassungs- und Regelungsprobleme), in: EuGRZ 1986, p. 469 - 478.

4 Jack Donnelly, International Human Rights in Theory and Practice, $2^{\text {nd }}$ ed., Ithaca and London, Cornell University Press, 2003, 16. 
Liber amicorum Eibe Riedel

human nature" (which "sets the 'natural' outer limits of human possibility") from "a moral vision of human nature" (according to which "human rights set the limits and requirements of social (especially state) action." $5 \mathrm{He}$ describes human nature as "a social project more than a presocial given" and thus is a "work of self-creation."

This essay focuses on "the scientist's human nature" and seeks to reopen the question of the scientific basis for understanding the relationship between human nature and human rights. Rather than separating experimental from speculative sciences, or biological sciences from moral philosophy, I propose a more integrated effort to understand what scientific investigation is defining as the "human" in need of protection through a regime of rights.

This reluctance to introduce scientific approaches to human nature into the study of human rights was not always the case. In the 17th and 18th centuries, the study of natural philosophy or "the workings of nature" was considered to include the concept of science as used in the 16th century and earlier as a synonym for knowledge or study. It was also closely linked with moral philosophy. In the 19th century the term "natural science" acquired its current meaning of knowledge acquired through experiments and empirical evidence and testing of hypotheses. This commingling and eventual separation of natural and moral philosophy will be discussed in section B.

In section $\mathrm{C}$, I will explore the idea that recent scientific investigation of human nature through evolutionary biology and neuroscience clarifies the theoretical foundation of human rights and provides a response to the challenge of the early 19th century English legal theorist and founder of utilitarianism Jeremy Bentham that, when confronted with the real word, human rights understood as "natural rights" are "nonsense upon stilts." This section will rely heavily on a recent book, quoted in the epigraph above, by Edward O. Wilson. Although many other biologists, psychologists, anthropologists, neuroscientists and philosophers have written on the origin of moral reasoning in ways that relate human nature to the assumptions of contemporary human rights, the breadth and clarity of Wilson's work amply justify drawing on The Social Conquest of Earth to open the dialogue on human nature and human rights. The conclusion in section D will evoke the concept of a "new Enlightenment" and the potential for synthesizing knowledge from biological and social sciences better to understand the relationship between human nature and human rights.

5 Donnelly (Fn. 4), 14.

6 Donnelly (Fn. 4), 15. 


\section{B. The Enlightenment Assumption that Human Rights Derive from HUMAN NATURE \\ 1. Merging of Science and Human Rights in the Enlightenment}

In the West, the theories of human rights that emerged in the $16^{\text {th }}$ and $17^{\text {th }}$ centuries formed the intellectual basis of revolutionary movements that generated declarations of rights, and at the same time were inseparable from the scientific revolution. The concept of "natural philosophy" applied to the scientific study of the physical and natural world. We are astounded today by the intellectual breadth of Diderot and Voltaire or Franklin and Jefferson, but their concern with astronomy, mathematics, chemistry, mechanics, and the diversity of human experience across the globe was integrated into their arguments for the Rights of Man. Thomas Paine exemplified the spirit of that time when he argued that human rights derive from human nature and that "[n]atural rights are those which appertain to man in the right of his existence."

The great achievements of Bacon and Descartes in the 17th and 18th centuries opened the way for innovation in mathematics, and experimental methods, which were well known to the political philosophers of the day. Through natural philosophy and natural rights, science and human rights were born of the same spirit of empiricism and progress that characterized the Enlightenment. In post-Enlightenment intellectual history human rights developed through moral reasoning, philosophical and political thought and legal theory and practice, with applications in the laws and institutions of human governance, administration of justice, and theories of the state. Natural Philosophy advanced through evolutionary biology, brain research, neuroscience, behavioural psychology, and related sciences.

The Enlightenment was indeed the critical period for science, medicine, and human rights. Referring to the scientific and democratic revolutions, Timothy Ferris in The Science of Liberty begins his study of this convergence by affirming, "These two transformations were linked, and remain so today: Every scientific nation in the world at the close of the twentieth century was a liberal, or at least partly liberal, democracy (meaning a state which guarantees human rights to its citizens, who elect their leaders)" ${ }^{8}$ He argues that these revolutions were not a coincidence, but rather that science sparked the democratic revolution and "that science

7 Thomas Paine, The Rights of Man, first published in London by J.S. Jordan, 1791, New York, Penguin Classics, 1983, 68.

8 Timothy Ferris, The Science of Liberty, Democracy, Reason, and the Law of Nature, New York: HarperCollins, 2010, 1. 
Liber amicorum Eibe Riedel

continues to foster political freedom today." 9

Aside from the possible fostering of political freedom by scientific advancement, the Enlightenment represents both the affirmation of the scientific method and the formulation of the human rights. The former reflected faith in human progress while the latter defined standards of freedom and equality on which the legitimacy of modern governments would henceforth be judged.

2. Development of Empirical Science in the 19th and 20th Century and Implications for Human Rights

The application of empirical methods to both natural sciences (including biology) and social sciences expanded significantly in the $19^{\text {th }}$ century with the emergence of thermodynamics, and electromagnetic theory, atomic theory (developed by John Dalton), evolutionary biology (based on the theory of natural selection in Darwin's The Origin of Species), experimental psychology (such as Wilhelm Wundt's Principles of Physiological Psychology and the work of people like James, Pavlov and Dewey) and sociology (especially Emile Durkheim's Rules of Sociological Method, as well as the work of Marx, Weber and many others). The $19^{\text {th }}$ century was also a period in which science was applied to industry, revolutionized the global economy and generated immense wealth. Per capita income increased more than nine times form 1820 to $2001 .{ }^{10}$

These extraordinary scientific developments were no longer conceived as part of a common project of modernity, in which human progress would advance with the simultaneous growth of science and industry, on the one hand, the establishment of human rights as the end of government, on the other. Unlike the scientific developments of the 17th and 18th centuries, those of the 19th century were deeply rooted in experimental methods and applications of advanced mathematics, without the need to sustain the linkage between the "two transformations." Indeed, the great economic strides of industrialized Europe and North American, made possible through advances in science and technology, were often achieved at the expense of colonized peoples and oppressed workers, and thus at the expense of human rights. Today globalization and the economic crises that accompany it, continue to challenge the human rights of formerly colonized peoples, as well as workers in the global North and South.

9 Ferris (Fn. 8) 2.

10 Angus Maddison, Growth and Interaction in the World Economy: The Roots of Modernity, Washington D.C.: The American Enterprise Institute, 2005, 5. See also Angus Maddison, Contours of the World Economy 1-2030 AD, Oxford University Press, 2007. 
The movements against slavery and the slave trade and for workers rights in the 19th and early 20th centuries, against colonialism in mid-20th century and against the harmful impacts of globalization and environmental degradation in the early 21 st century were successful to the extent that they were able to challenge the economic interests that relied so much on scientific progress. The technology that created and sustained the Industrial Revolution seems to have reversed the Enlightenment approach to human rights and advances in science and technology as two mutually reinforcing dimensions of human progress.

This is not to say that scientific progress is necessarily detrimental to human rights. On the contrary, the right to benefit from scientific progress was proposed as a human right by the Committee on the Theoretical Bases of Human Rights in 1947, ${ }^{11}$ and incorporated in Article 27 of the Universal Declaration of Human Rights in 1948 and Article 15 of the International Covenant on Economic, Social and Cultural Rights in 1966. Of course, scientists have been active in human rights in a variety of ways ${ }^{12}$ but the issue I wish to address is that they rarely draw implications for human rights from their work. This is due in large part to the fact that the connections are not always evident and that most empirical scientists hesitate to take a

11 Such was the position taken in 1947 by the UNESCO-convened Committee on the Theoretical Bases of Human Rights, which sought to clarify the underlying concepts of the draft Universal Declaration. Its statement on the "Grounds of an International Declaration of Human Rights" of July 1947, included a "Right to Share in Progress" according to which "Every man has the right to full access the enjoyment of the technical and cultural achievements of civilization."Unesco, Human Rights: Comments and Interpretations. A Symposium Edited by Unesco, UNESCO/PHS/3(rev.), 25 July 1948, Appendix II, p. 14. The right was subsequently recognized in Article 25 of the UDHR and Article 25 of the International Covenant on Economic, Social and Cultural Rights.

12 Richard Pierre Claude, Science in the Service of Human Rights, University of Pennsylvania Press, 2003; Carol Corillon, "The Role of Science and Scientists in Human Rights," The ANNALS of the American Academy of Political and Social Science, vol. 506 (November 1989), pp. 129-140. The American Association for the Advancement of Science (AAAS) currently hosts a Science of Human Rights Coalition, consisting of scientific and engineering membership organizations, which facilitates "communication and partnerships on human rights within and across the scientific community, and between the scientific and human rights communities." http://shr.aaas.org/coalition/index.shtml (Visited 16 August 2012). 
Liber amicorum Eibe Riedel

position on matters outside of their specialized fields. The next session explores the human rights implications of twentieth century scientific advances in understanding human nature, beginning with biology.

\section{Human Rights Implications of Scientific Knowledge about Human NATURE}

Although a contested concept, "human nature" has been understood as a combination of genetic and cultural factors determining human behaviour. Wilson describes human nature as the "monster in the fever swamp of public discourse," 13 but finds "that ample evidence, arising from multiple branches of learning in the sciences and humanities, allows a clear definition of human nature." His definition-which is an excellent starting point for reflecting on the implications for human rights - is "the inherited regularities of mental development common to our species," and the result of "the interaction of genetic and cultural evolution that occurred over a long period in deep prehistory." "These interactions generate "epigenetic rules" of psychological development, which, he is quick to point out "are not genetically hardwired." 15

Paul Ehrlich explains in Human Natures, "[h]uman natures are clearly the result of biological and cultural evolution, and in some sense the ethical feelings and behaviors that are part of our natures must have arisen through these same processes." 16 He cautions, however, that only the capacity to develop ethics, that is, to anticipate consequences, feel empathy, internalized societal standards, and make moral choices, derives from human biology; "the actual ethics, morals, and norms of a society - the products of that ethical capacity - are overwhelmingly a result of cultural evolution within that society." 17

Scientific discussion of the tension in human nature between genetic vs. cultural factors and between individual egoism and group identity has rarely been linked to human rights. One of the papers presented to the Committee on the Theoretical Bases of Human Rights in 1947 dealt with human rights protection of individuals in tension with that of groups from the biological perspective. R. W. Gerard, professor of physiology at the University of

13 Wilson (Fn. 2), 191.

14 Wilson (Fn. 2), 192.

15 Wilson (Fn. 2). 194.

16 Paul R. Ehrlich, Human Natures: Genes, Cultures, and the Human Prospect. Washington, D.C.: Island Press/Shearwater Books, 2000, p. 308.

17 Ehrlich (Fn. 16), 308-309. 
Chicago, wrote, "The central problem of man in society is that of outlining the territory of the individual within the larger territory of the group. ... This is the inescapable dichotomy: each man (and his neighbour) is a complete whole, dedicated to self-survival and in basic competition with other men; but each man (and his neighbour) is a component unit of a larger whole, the society, and dedicated to group survival by basic cooperation with other men in that group." "This simple fact has implications for human rights. According to Gerard, "Man's rights and duties, then, cannot be absolute but remain always relative to his milieu... The 'rights of man' are attempts to define the territory of the individual (or the small group) vis-àvis his neighbours and larger groups." 19 Affirming that "social evolution cannot violate general laws of biological evolution," he acknowledges that "the biologist cannot supply details of what present human rights should be." ${ }^{20}$ Nevertheless, he assesses human rights from a biological perspective by reiterating several general laws of biological evolution, including:

Greater dependence of the individual on the group is in the line with evolution. Altruism is growing relative to selfishness... Any doctrine which regards man only as an individual or only as a unit in a group is necessarily false. The duality of man, as an individual whole and as a social unit, is inescapable. The extremes of eudemonism and utilitarianism, individualism and collectivism, anarchism and totalitarianism, laissez-faire and absolute economic socialism are untenable. The rights of man involve rights of the individual (or small group) as against other individuals (or groups) or the whole society - which implies duties of them to him - and rights of the whole (or small group) as against the individual (or group) - which implies duties of him to it. ${ }^{21}$

In that same symposium, international lawyer Quincy Wright began his reflections by noting that "biologists tell us that all men share with the higher animals desires of varying intensity for life, for food, for sex, and for dominance. The psychologists add the desire for home territory, for personal freedom, for movement and for society." 22 He concluded, [h] uman

18 R. W. Gerard, "The Rights of Man: A Biological Approach," in Jacques Maritain, ed., Human Rights: Comments and Interpretations, London/New York, Allan Wingate [Originally issued as UNESCO Doc. PHS/3 (rev.)], 205-206.

19 Gerard (Fn. 18), 206-207.

20 Gerard (Fn. 18), 208.

21 Gerard (Fn. 18), 208-209.

22 Quincy Wright, "Relationship between Different Categories of Human Rights, in Maritain (Fn. 18), 143. 
Liber amicorum Eibe Riedel

rights can only be defined if due consideration is given both to the original nature of man and to the contemporary standards of world civilization. ${ }^{23}$

Since then, enormous progress has been made in evolutionary biology and neuroscience but little attention has been devoted to the question of whether these scientific fields clarify the relation between the scientific understanding of human nature and the impact of that understanding on theories of human rights. Evolutionary biology and neuroscience accomplished major breakthroughs in the 20th century but the training and institutional settings of the scientists involved rarely offered the occasion to engage with moral philosophers, international and constitutional lawyers, and political scientists, as they did in 1947.

Evolutionary biology is a particularly rich field from the human rights perspective insofar as it explores the extent to which behaviour assumed to be essential to human rights (such as avoiding harm to others, treating other as equals) is explained by inherited genes or by socialisation. It also examines whether human morality serves a purpose in natural selection. Echoing Gerard's "inescapable dichotomy," Wilson finds the following "iron rule in genetic social evolution": "Selfish individuals beat altruistic individuals, while groups of altruists beat groups of selfish individuals." 24 it is "natural" for humans to take from others and to kill other humans whenever there is an advantage, including on a mass scale. Like all social species, humans function in hierarchical relations with other humans. The propensity to accept hierarchical social structures is innate in humans. What does this dimension of "human nature" tell us about the problems of equality and violence in human rights terms?

\section{The Problem of Equality and Non-discrimination}

This combination of a genetically inherited propensity and a sociallydetermined behaviour challenges the claim of most human rights documents that "all human beings are born equal." This concept was addressed in the canonical texts of the Eighteenth century revolutions, beginning with the American Declaration of Independence ("all men are created equal") and in Article 1 of the French Declaration of 1789, identical to that of 1791: "Men are born and remain free and equal in rights. Social distinctions may be founded only upon the general good." In Anarchical Fallacies, Jeremy Bentham's scathing critique of the 1791 Declaration, he said regarding this article:

All men are born free? All men remain free? No, not a single man:

23 Wright (Fn. 22), 151.

24 Wilson (Fn. 2), 243. 
not a single man that ever was, or is, or will be. All men, on the contrary, are born in subjection, and the most absolute subjection--the subjection of a helpless child to the parents on whom he depends every moment for his existence. ... All men born free? Absurd and miserable nonsense! ... All men are born equal in rights. The rights of the heir of the most indigent family equal to the rights of the heir of the most wealthy? ... All men (i.e. all human creatures of both sexes) remain equal in rights. ... The apprentice, then, is equal in rights to his master; ... So again as between wife and husband. The madman has as good a right to confine anybody else, as anybody else has to confine him. ${ }^{25}$

This diatribe goes on at length (and Bentham's Anarchical Fallacies contains much more in this vein on this and each of the articles of the French Declaration) and includes his famous assessment of "natural rights" as "simple nonsense" and "natural and imprescriptible rights" as "rhetorical nonsense--nonsense upon stilts." 26 From the "laws of nature," he explained, "come imaginary rights, a bastard brood of monsters.",27

Was Bentham's critique a reflection of a finding of evolutionary biology that humans are hierarchical? Clearly humans are born unequal in status, property, genetic endowments, access to the social determinants of good health and in numerous other aspects. An yet the Universal Declaration's opening article reads "All human beings are born free and equal in dignity and rights. They are endowed with reason and conscience and should act towards one another in a spirit of brotherhood."

The claim that equality derives from human nature constitutes what Bentham called an anarchical fallacy. He argued, "[t]here are no such things as natural rights - no such things as rights anterior to the establishment of government-no such things as natural rights opposed to, in contradistinction to, legal rights."

Bentham criticizes natural law because it confuses what ought to be with what is and thus commits the "naturalistic fallacy" in the common sense of the expression. ${ }^{28}$ The critique holds insofar as it rejects the assertion that a behaviour (e.g., treating people equally) is a human right

25 Jeremy Bentham, Anarchical Fallacies; Being an Examination of the Declarations of Rights Issued During the French Revolution, in The Works of Jeremy Bentham published under the superintendence of his Executor, John Browning, vol. two, New York: Russell \& Russell, Inc., 1962, [originally published in 1843], 498-499.

26 Bentham (Fn. 25), 501

27 Bentham (Fn. 25), 523. 
Liber amicorum Eibe Riedel

because it corresponds to a theoretical state of nature (e.g., all humans are born equal). It is both factually wrong that humans are born equal and morally dangerous to want to make a right out of what occurs naturally. Slavery, genocide, patriarchy, and discrimination based on class, sex, caste, social origin, ethnicity, language or religion occur "naturally" in human societies. It is clear therefore that the current corpus of human rights has not relied on the idea that what humans are known to do with sufficient regularity as to be their "natural" behaviour merits being enshrined as a "natural" right.

Part of the confusion stems from the concept of the "state of nature," as defined by Locke, Hobbes, Rousseau, and Hume, that is, the condition of early man before the state, laws and other constraints under the social contract. Although this state of nature is pure speculation of Enlightenment philosophers, it is extraordinary the extent to when their descriptions resemble that of more recent paleontology. Consider how Rousseau described the "savage": "Accustomed from their infancy to the inclemencies of the weather and the rigour of the seasons, inured to fatigue, and forced, naked and unarmed, to defend themselves and their prey from other ferocious animals or to escape them by flight, men would acquire a robust and almost unalterable constitution." ${ }^{29}$ Under the state of nature, man has "natural liberty and an unlimited right to everything he tries to get and succeeds in getting," which he gives up in the social contract in exchange for "civil liberty and the proprietorship of all he possesses."

Human rights have been based on the assumption of the perfectibility of human society and that altering behaviour based on moral precepts is possible through law and education, what Donnelly calls "a self-fulfilling moral prophecy." 31 Thus it is not the observed nature of humans (unequal at birth, in competition with other individual, prone to violence) but the morally preferable nature than matters (equality, respecting other individuals). At the level of the group, altruism is "natural" in some circumstances but does not ipso facto provide a basis for human rights

28 The naturalistic fallacy also understood in philosophy as the error of assuming, because some thing or act has a property, such as being pleasant, and pleasantness is good, that therefore the thing or act in question is always good. Such was the position of the philosopher G. E. Moore in his 1903 book Principia Ethica.

29 Jean-Jacques Rousseau, Discourse on the Origin of Inequality, originally published 1755, quoted from The Social Contract and Discourses, translated by G.D.H. Cole, ed. By P. D. Jimack, London, Orion Publishing, 1993, 53.

30 Rousseau (Fn. 29), 196.

31 Donnelly (Fn. 4), 15. 
norms.

According to Wilson, "A basic element of human nature is that people feel compelled to join groups and, having joined, consider them superior to competing groups." 32 This feature of human nature is acknowledged in the "the right to freedom of peaceful assembly and association," 33 which is reaffirmed in all general human rights texts. In order to reduce the consequences of the propensity of members of the group to consider their group superior to others and to compete, there is a concomitant human right that no human right, including freedom of association, "may be interpreted as implying for any State, group or person any right to engage in any activity or to perform any act aimed at the destruction of any' other right." 34 The juxtaposition of these two principles of human rights (freedom of association and non-use of a right to destroy other rights) is in the logic of human rights. It respects the need of humans to associate with other humans, while protecting the weaker groups from potential harm from competing groups that would deny the very right to exist of the weaker group.

The problem of equality and non-discrimination thus brings into focus the importance of constantly distinguishing what is considered morally good from what is observable in nature. Human rights set a high standard of equality, which assumes that humans can overcome traits of domination that have served individuals in natural selection but which are, in the logic of human rights, contrary to the longer-term interests of groups.

\section{Cooperation and Competition among Human Groups}

To understand the extent to which it is "natural" for humans to aspire toward cooperation and mutual respect (or to "act towards one another in a spirit of brotherhood" in the language of the UDHR), we need to inquire into the concepts of altruism and empathy. These behaviours can be explained in evolutionary terms as a result of the advantage derived by the group where certain individuals sacrifice reproductive potential in the interest of the group, in contrast to populations in which all individuals pursue selfish interests. While selfishness is truly a feature of inherited individual behaviour, altruism is also deeply inbedded in human nature. Evolutionary biology teaches us that altruism emerged as cooperation within the in-group and as hostility toward the out-group.

32 Wilson (Fn. 2), 290.

33 Universal Declaration of Human Rights (UDHR), article 20.

34 UDHR, article 30. 
Altruism had been explained by the "inclusive fitness theory," developed by William Hamilton and others in a 1964 articles in the Journal of Theoretical Biology. The theory holds that the genes for altruism could evolve if relatedness or kinship (r) makes the benefit to the individual (B) of an action exceed the cost (C) to the individual, expressed in the formula $\mathrm{rB}$ $>$ C. This inclusive fitness theory prevailed for three decades until several scientists, including Wilson, reconsidered it in the 1990s because the mathematics did not work out and empirical evidence could not be produced to support it. ${ }^{35}$ Wilson replaces it with standard models of population genetics.

I n The Social Conquest of Earth, Wilson explains the concept of eusociality (the highest level of social organisation), that is, the complex social system of a limited number of species, like ants, termites, wasps and humans, that "divide labor in what outwardly at least appears to be an altruistic manner," 36 creating superorganisms having a comparative advantage over other organisms. His explanation of altruism and thus of moral behaviour is that " $[\mathrm{h}]$ man beings are prone to be moral- do the right thing, hold back, give aid to others, sometimes even at personal riskbecause natural selection has favored those interactions of groups members benefitting the group as a whole." ${ }^{37}$

Cooperation is even more important for him in that it favours groups with a higher proportion of co-operators over other groups. His conclusion on this point holds considerable potential for clarifying the relationship between human nature and human rights: "we [humans] are unique among animals in the degree that we attend to the sick and injured, help the poor, comfort the bereaved, and even willingly risk our own lives to save strangers." ${ }^{38}$ In sum, "authentic altruism is based on a biological instinct for the common good of the tribe, put in place by group selection, wherein groups of altruists in prehistoric times prevailed over groups of individuals in selfish disarray." 39

From this perspective, it is not difficult to see the motivation behind such human rights standards as the right of everyone "to a standard of living

35 Wilson (Fn. 2), 167-182. The story of the controversy surrounding Wilson recantation of inclusive fitness is told in Jonah Lehrer, "Kin and Kind: A fight about the genetics of altruism", The New Yorker, March 5, 2012, p. 40-42.

36 Wilson (Fn. 2), 109.

37 Wilson (Fn. 2), 247.

38 Wilson (Fn. 2), 250.

39 Wilson (Fn. 2), 251. 
adequate for the health and well-being of himself and of his family, including food, clothing, housing and medical care and necessary social services, and the right to security in the event of unemployment, sickness, disability, widowhood, old age or other lack of livelihood in circumstances beyond his control." (UDHR, Article 25). This norm, and the more detailed enumeration of economic, social and cultrual rights in human rights treaties, was not drafted with natural selection in mind but in effect favours the "authentic altrusim" to which Wilson refers.

\section{The Problem of Violence}

On the subject of violent behaviour in human evolution, Sam Harris explains in The Moral Landscape, "Human evil is a natural phenomenon, and some level of predatory violence is innate in us." ${ }^{40}$ In The Better Angels of Our Nature, Steven Pinker discusses the "dark side of Human Nature."41 He identifies raw exploitation, dominance, revenge, and ideology as dimensions of human nature that militate toward violence. Pinker thinks ideology might be the biggest contributor to violence, especially on a large scale. Rape, plunder, conquest, and the elimination of rivals have been part of a natural drive toward dominance. His book has its detractors but clearly poses the core problem of human nature and human rights and documents the dramatic decline of violence over the centuries in all parts of the world, as measured by deaths through genocide, war, human sacrifice, and homicide and by behavior such as torture, slavery, and the treatment of racial minorities, women, children, and animals. Other behaviours reflect a thirst for revenge that can take the form of vendettas, rough justice, and cruel punishments.

Pinker further finds countervailing traits of human nature in self-control, empathy, the moral sense, and reason. Among the trends that he considers as having moderated these forms of violence is what he calls the "Rights Revolution" and the "Humanitarian Revolution." These events as described by Pinker are related to but not coterminous with contemporary human rights and humanitarian law. The point is worth pondering from the human rights perspective: Human societies have made considerable progress in creating and enforcing human rights and humanitarian norms, which perhaps exemplify the potential imbedded in human nature to restrain ourselves from violence and other behaviours harmful to what we value in human existence.

40 Sam Harris, The Moral Landscape. How Science Can Determine Human Values, New York, Free Press, 2010, 100.

41 Steven Pinker, The Better Angels Of Our Nature: How Violence Has Declined, New York: Viking Press, 2011. 
Liber amicorum Eibe Riedel

Wilson explains that "our bloody nature ... is ingrained because groupversus-groups was a principal driving force that made us what we are" 42 and "war and genocide have been universal and eternal, respecting no particular time or culture."43 For Wilson, a lesson from the study of the biological origins of moral reasoning is that all agree that genocide, slavery, and child abuse "should be opposed everywhere without exception". ${ }^{44}$ Of course all of these are clearly banned without exception in human rights texts and implementation mechanisms.

Pinker, Harris and Wilson share the view that our species is capable of rising above our violent nature, our dark side, through moral codes and enforcement of law. From this perspective, we can consider whether the human rights norms governing violent acts are legitimate and reasonable instruments to fulfil moral preferences emerging collectively in our species. Consider the rights to life and security of person (Article 3 of the UDHR), or the prohibition of slavery or servitude (Article 4), or the ban on torture or to cruel, inhuman or degrading treatment or punishment (Article 5), or the 1948 Convention on the Prevention and Punishment of the Crime of Genocide Convention, or the 1993 Declaration on the Elimination of Violence against Women. These provisions refer to behaviours that are "natural" in human history but that all governments participating in the United Nations agree to eliminate. In other words, the promotion and protection of human rights reflect efforts to change behaviours deeply embedded in human nature.

Marc Hauser, one of the best known scholars in the field of moral psychology (and who resigned from his faculty position at Harvard University in 2011 following an internal investigation that found him responsible for scientific misconduct, apparently not related to his work in Moral Minds) seems to acknowledge the value of such developments when he refers to "the positive effects of organizations such as the United Nations [where] we see the spread of particularly virtuous moral attitudes." $45 \mathrm{He}$ concludes, "It is thus possible for some groups to facilitate the spread of what many consider universal rights." ${ }^{, 46}$

42 Wilson (Fn. 2), 62.

43 Wilson (Fn. 2), 65.

44 Wilson (Fn. 2), 254.

45 Marc Hauser, Moral Minds. The Nature of Right and Wrong, New York, HarperCollins, 2006, 311.

46 Hauser (Fn. 45), 311. 


\section{Conclusion: A New Enlightenment for Understanding the Relations betweEn Human Nature and Human Rights}

The relationship between human nature and human rights was essential to the emergence of modernity during the Enlightenment insofar as human rights were deemed to derive from human nature. That relationship has evolved radically in the sense that most human rights seek to limit behaviours that are regarded constant features of human nature.

A more nuanced interpretation of this relationship might consider individual autonomy and freedom as aspirations deriving from the egoist in human nature, the selfish individual seeking procreative advantage. These traits reflect underlying concerns of many civil and political rights. Those traits that translate into behaviours of cooperation and concern for others derive from altruism and empathy in human nature, and find expression in economic, social and cultural rights. While this categorization of rights has its limits, ${ }^{47}$ there is a common recognition in the legal formulation of human rights and in the biological understanding of human nature that humans are self-centred and aspire to enjoy freedom, on the one hand, and compassionate and willing to accept duties toward others, on the other. Developments in biology, psychology and neuroscience are shedding light on the biological origins of moral reasoning such that we can now consider that it is consistent with human nature for societies to formulate and protect human rights aimed at altering human behaviour.

In discussing violence above, we noted that Wilson listed condemnation of slavery, child abuse, and genocide as the "clearest ethical precepts" on which all agree and that this list could be expanded "with deepened selfawareness" to "precepts shared by most societies" which "will stand the test of biology-based realism." 48 But he added that outside of these "there is a grey domain inherently difficult to navigate" and about which inquiry into the biological history "has not been done. In fact, it is seldom even imagined." ${ }^{\prime 9} \mathrm{He}$ anticipates that such issues as gay rights, contraception and forced marriage will not "stand the test of biological realism.",50

The record of human rights bodies dealing with these and many other

47 I have argued elsewhere that this categorization has outlived its usefulness and that a more holistic and integrated understanding of human rights is preferable. Stephen P. Marks, "The Past and Future of the Separation of Human Rights into Categories," Maryland Journal of International Law, vol. 24 (2009), 208-241.

48 Wilson (Fn. 2), 254

49 Wilson (Fn. 2), 254.

50 Wilson (Fn. 2), 254. 
Liber amicorum Eibe Riedel

issues in the "grey domain" turns out to be more promising than Wilson anticipates, whether we consider the Convention on Consent to Marriage, Minimum Age for Marriage and Registration of Marriages, which entered into fore in 1964, the Yogyakarta Principles on the Application of International Human Rights Law in relation to Sexual Orientation and Gender Identity drafted in $2006,{ }^{51}$ or the UN Declaration on Sexual Orientation and Gender Identity, or progress in reproductive and sexual rights since the Cairo International Conference on Population and Development in $1994 .^{52}$

No one claims that these matters are settled, as is evident from the deliberations of the Human Rights Council. Nevertheless, civil society and international bodies have produced considerable normative clarity beyond Wilson's "clearest ethical precepts." The work of the Committee on Economic, Social and Cultural Rights, where Eibe Reidel has played an outstanding role since 2003, has dealt with many matters in the "grey domain," although without submitting to the "test of biological realism." To the extent that emerging human rights norms challenge behaviours common to human societies for millennia (such as gender stereotyping, discrimination, inequality in access to basic goods, violence), it is not an exaggeration to consider that they seek to reverse the course of human nature.

Several natural scientists have addressed the deep origins of moral reasoning and, by implication, of human rights. Alex Walter writes in "The Anti-Naturalistic Fallacy" that an evolutionary study of morality would enable us to investigate "how people came to acquire ethical concepts... how they make ethical judgments... and how they construct ethical systems," as well as to "derive new ethical principles from a combination of newly discovered facts and already accepted normative principles"; an evolutionary study of ethics could "explain meta-ethics, i.e. provide the foundation that underlies our ethical beliefs and behavior," and possibly "justify new and different ethical norms." 53

Hauser found that "[o]ur moral faculty is equipped with a universal moral grammar, a toolkit for building specific moral systems." ${ }^{54} \mathrm{He}$ further

51 See http://www.yogyakartaprinciples.org (visited 6 August 2012.)

52 A/CONF.171/13/Rev.1 -- Report of the International Conference on Population and Development, U.N. Doc. A/CONF.171/13/Rev.1 (1994).

53 Alex Walter, "The Anti-naturalistic Fallacy: Evolutionary Moral Psychology and the Insistence of Brute Facts," Evolutionary Psychology 4 (2006): 33-48.

54 Hauser (Fn. 45), xviii. (Emphasis in the original.) 
explains that "an unconscious and universal moral grammar underlies our judgments of right and wrong." ${ }^{55} \mathrm{He}$ considers that many failed policies in law, politics, business and education result from "our ignorance about the nature of our moral instincts." ${ }^{56}$ Natural selection does not provide the answer to moral behaviour as "there aren't enough genes to code the various required behaviors" but rather "cultural evolution is the source of ethics" 57 and, therefore, of human rights.

In what is perhaps the only work by a neuroscientist that places his scientific field squarely in the context of human rights, Jean-Pierre Changeux in The Physiology of Truth explicitly draws on the Universal Declaration of Human Rights and other human rights texts to claim that "The development of science has led, indirectly, to a gradual recognition of human rights." ${ }^{58}$ At the conclusion of his study, he proposes an ambitious intercultural dialogue on ethical questions, the purpose of which would be "to discover and explain the aspirations and beliefs of human beings - in short, their mental states and expectations of reward - [and bring] about the good life that all human beings desire ... [and to achieve] a more harmonious balance between the rights of the individual and the needs of human society." 59 Essentially, Changeux proposes an advisory committee, under UN auspices, to draw on the sciences, particularly the biological and medical sciences, to address ethical issues and make recommendations regarding "actual causes of human suffering in a detailed and practical way." 60

It is accepted in the biological study of human nature, as Ehrlich put it, that "[h] uman beings are the only animals that have developed religions, ethics, moral codes, and mutually agreed-on norms of conduct. These are human universals, but micro- and macroevolution have combined to produce a multitude of forms in different societies." 61 Thus, those who study human nature might benefit from introducing explicit knowledge of human rights norms into their reflections on moral codes as products of human self-reflection. As Hauser suggested, "Inquiry into our moral nature will no

55 Hauser (Fn. 45), xviii

56 Hauser (Fn. 45), xx.

57 Ehrlich (Fn. 16), 317.

58 Jean-Pierre Changeux, The Physiology of Truth. Neuroscience and Human Knowledge, Cambridge, MA: Harvard University Press, 2002, 236.

59 Changeux (Fn. 58), 261-262.

60 Changeux (Fn. 58), 263.

61 Ehrlich (Fn. 16), 256. 
Liber amicorum Eibe Riedel

longer be the proprietary province of the humanities and social sciences, but a shared journey with the natural sciences." 62

The principal claim of this essay is that such research will enhance our understanding of human rights and human nature if pursued rigorously. Without there being a need for the body Changeux proposes (which seems to be a mix of the current International Bioethics Committee of UNESCO and the Human Rights Council Advisory Committee), there is ample room for more research drawing on emerging knowledge in the life sciences, social sciences, neuroscience, humanities and psychology about human nature with explicit reference to the implication so for human rights. This is the first argument Wilson makes for a "new Enlightenment." ${ }^{63}$ His second argument is equally compelling: "The planet we have conquered is not just a stop along the way to a better world out there in some other dimensions. Surely one moral precept we can agree on is to stop destroying our birthplace, the only home humanity will ever have."

The genius of the Enlightenment was the synthesis of knowledge in ways that had major impacts on human affairs, principal among which were scientific progress and defining and enforcing human rights. A new Enlightenment would mean an intellectual reconnecting of moral philosophy regarding human rights and extraordinary advances in scientific understand of human nature. The challenges of climate change, genomics, nanotechnology, green energy, robotics, neuroscience, to name but a few areas of extraordinary developments of this century, call for such a new Enlightenment. The $18^{\text {th }}$ century Enlightenment was the launching pad of modern scientific method and of modern government respectful of human rights. Three hundred years later, there is much to be gained by restoring the willingness to cross disciplinary boundaries and seek new insights regarding the human condition.

62 Hauser (Fn. 45), 425.

63 Wilson (Fn. 2), 289-291.

64 Wilson (Fn. 2), 294. 